\title{
Paracoccus aestuarii sp. nov., isolated from tidal flat sediment
}

\author{
Seong Woon Roh, ${ }^{1,2}$ Young-Do Nam, ${ }^{1,2}$ Ho-Won Chang, ${ }^{1,2}$ \\ Kyoung-Ho Kim, ${ }^{1,2}$ Min-Soo Kim, ${ }^{1,2}$ Kee-Sun Shin, ${ }^{2}$ Jung-Hoon Yoon, ${ }^{2}$ \\ Hee-Mock Oh ${ }^{2}$ and Jin-Woo Bae ${ }^{1,2}$ \\ ${ }^{1}$ Department of Biology, Kyung Hee University, Seoul 130-701, Republic of Korea \\ ${ }^{2}$ University of Science \& Technology, Biological Resources Center, KRIBB, Daejeon 305-806, \\ Republic of Korea
}

Correspondence

Jin-Woo Bae

baejw@kribb.re.kr

\begin{abstract}
A Gram-negative micro-organism, designated strain $B 7^{\top}$, was isolated from tidal flat sediment and subjected to a polyphasic taxonomic study involving morphological, physiological, biochemical and 16S rRNA gene sequence analyses. A phylogenetic analysis based on the 16S rRNA gene sequence indicated that strain $B 7^{\top}$ belonged to the genus Paracoccus and was closely related phylogenetically to Paracoccus marcusii $\mathrm{MH}^{\top}{ }^{\top}$ (97.5\% sequence similarity), Paracoccus marinus KKL-A5 ${ }^{\top}$ (97.5\%), Paracoccus haeundaensis $\mathrm{BC} 7171^{\top}$ (97.3\%), Paracoccus carotinifaciens E-396 ${ }^{\top}$ (97.3\%), Paracoccus homiensis DD-R11 ${ }^{\top}$ (97.2\%), Paracoccus seriniphilus MBT-A4 ${ }^{\top}$ $(96.9 \%)$ and other type strains of the genus Paracoccus (95.2-96.7\%). The $\mathrm{G}+\mathrm{C}$ content of the genomic DNA and the major isoprenoid quinone of the type strain were $62.0 \mathrm{~mol} \%$ and ubiquinone-10, respectively. The major fatty acid components were $\mathrm{C}_{18: 1} \omega 7 \mathrm{c}(68.9 \%)$ and $\mathrm{C}_{18: 0}(18.1 \%)$; this profile, with $\mathrm{C}_{18: 1} \omega 7 \mathrm{c}$ as the predominant fatty acid, was characteristic of members of the genus Paracoccus. The 16S rRNA gene sequence analysis, DNA-DNA hybridization studies and physiological and biochemical tests identified genotypic and phenotypic differences between strain $B 7^{\top}$ and recognized Paracoccus species. On the basis of these data, therefore, strain $B 7^{\top}$ represents a novel species of the genus Paracoccus, for which the name Paracoccus aestuarii sp. nov. is proposed. The type strain is $B 7^{\top}\left(=\right.$ KCTC $22049^{\top}=\mathrm{DSM}$ $19484^{\top}=$ JCM $15119^{\top}$ ).
\end{abstract}

The genus Paracoccus belongs to the Alphaproteobacteria and was first proposed by Davis et al. (1969) as comprising a Gram-negative, catalase-positive, oxidase-positive bacterium, Paracoccus denitrificans. Members of this genus contain $\mathrm{C}_{18: 1} \omega 7 \mathrm{c}$ as a major component of the cellular fatty acids and are metabolically versatile. At the time of writing, since this genus was proposed in 1969, the names of 24 species belonging to the genus Paracoccus have been validly published, having been isolated from various environments including soil, sediment and activated sludge. The purpose of this paper was to establish the taxonomic position of strain $\mathrm{B}^{\mathrm{T}}$, which was isolated from tidal flat sediment, on the basis of data from phenotypic, genetic and chemotaxonomic analyses.

Strain $\mathrm{B}^{\mathrm{T}}$ was isolated from tidal flat sediment in Yeosu $\left(34^{\circ} 47^{\prime} 26^{\prime \prime} \mathrm{N} 127^{\circ} 34^{\prime} 01^{\prime \prime} \mathrm{E}\right)$, South Korea. This novel strain was isolated on TSBA (tryptic soy broth solidified with 20.0 g agar $\mathrm{l}^{-1}$; Difco) and a pure culture was obtained

The GenBank/EMBL/DDBJ accession number for the 16S rRNA gene sequence of strain $B 7^{\top}$ is EF660757. by using repeated restreaking. Cell biomass for analysis of cellular composition and for DNA extraction was taken from TSBA plates that had been incubated at $30{ }^{\circ} \mathrm{C}$ for 2 days.

A DNA-extraction kit (G-spin, iNtRON Biotechnology) was used to obtain chromosomal DNA. Two universal bacterial primers: forward primer $27 f \quad\left(5^{\prime}-\right.$ AGAGTTTGATCCTGGCTCAG-3') and reverse primer 1492r (5'-TACGGYTACCTTGTTACGACTT-3') (Lane, 1991) were used to PCR-amplify the $16 \mathrm{~S}$ rRNA gene from the chromosomal DNA. After purification with a PCR purification kit (Solgent), the PCR product was sequenced as described previously (Roh et al., 2008). SeqMan software (DNASTAR) was used to assemble full-length 16S rRNA gene sequences. The identification of phylogenetic neighbours and the calculation of pairwise $16 \mathrm{~S}$ rRNA gene sequence similarities were achieved using the EzTaxon server (http://www.eztaxon.org/; Chun et al., 2007). 16S rRNA gene sequences from the novel isolate and related taxa (NCBI database) were aligned using the multiple sequence alignment program CLUSTAL_X (version 1.8) 
(Thompson et al., 1997). Phylogenetic relationships between representative Paracoccus species were determined using the MEGA3 software program (Kumar et al., 2004). Dendrograms were elaborated by means of distance matrices (Kimura, 1980), using the neighbour-joining method (Saitou \& Nei, 1987). To evaluate the stability of the trees, a bootstrap analysis was performed using a consensus tree that was based on 1000 randomly generated trees. DNA-DNA hybridization was performed using the fluorometric method of Ezaki et al. (1989). Phylogenetic analysis based on $16 \mathrm{~S}$ rRNA gene sequences indicated that strain $B 7^{\mathrm{T}}$ falls within the cluster of Paracoccus species (Fig. 1) and is closely related phylogenetically to Paracoccus marcusii $\mathrm{MH}_{1}^{\mathrm{T}}$ ( $97.5 \%$ sequence similarity), Paracoccus marinus KKL-A5 ${ }^{\mathrm{T}}(97.5 \%)$, Paracoccus haeundaensis $\mathrm{BC} 7171^{\mathrm{T}}(97.3 \%), \quad$ Paracoccus carotinifaciens $\mathrm{E}-396^{\mathrm{T}}$ (97.3\%), Paracoccus homiensis DD-R11 ${ }^{\mathrm{T}} \quad(97.2 \%)$, Paracoccus seriniphilus MBT-A4 ${ }^{\mathrm{T}}$ (96.9\%) and other type strains of the genus Paracoccus (95.2-96.7\%). A DNADNA hybridization study revealed the following mean levels of DNA-DNA relatedness between strain $\mathrm{B}^{\mathrm{T}}$ and the type strains of its closest relatives in the phylogenetic tree: $P$. marcusii $(9.4 \%), \quad P$. homiensis $(13.9 \%)$ and $P$. seriniphilus $(11.3 \%)$. P. haeundaensis $\mathrm{BC} 74171^{\mathrm{T}}$ and $P$. carotinifaciens $\mathrm{E}-396^{\mathrm{T}}$ are patent strains that are not publicly available, so a DNA-DNA relatedness study could not be conducted with these two strains. Species definitions can be established with DNA-DNA reassociation values below $70 \%$ (Wayne et al., 1987), and 16S rRNA gene sequence similarity values that are less than $98.7 \%$ between two strain pairs have DNA-DNA reassociation values of less than $70 \%$ (Stackebrandt \& Ebers, 2006); therefore, strain $B 7^{\mathrm{T}}$ can be considered to represent a distinct genospecies.

The DNA G $+\mathrm{C}$ content was determined using HPLC as described by Mesbah \& Whitman (1989), with Escherichia coli B (Sigma-Aldrich) as the calibration reference. The $\mathrm{G}+\mathrm{C}$ content of the genomic DNA of the type strain was $62.0 \mathrm{~mol} \%$. The lowest genomic DNA G $+\mathrm{C}$ content among species belonging to the genus Paracoccus is $61.3 \mathrm{~mol} \%$ (for the type strain of Paracoccus sulfuroxidans; Liu et al., 2006) and the highest value is $71.0 \mathrm{~mol} \%$ (for the

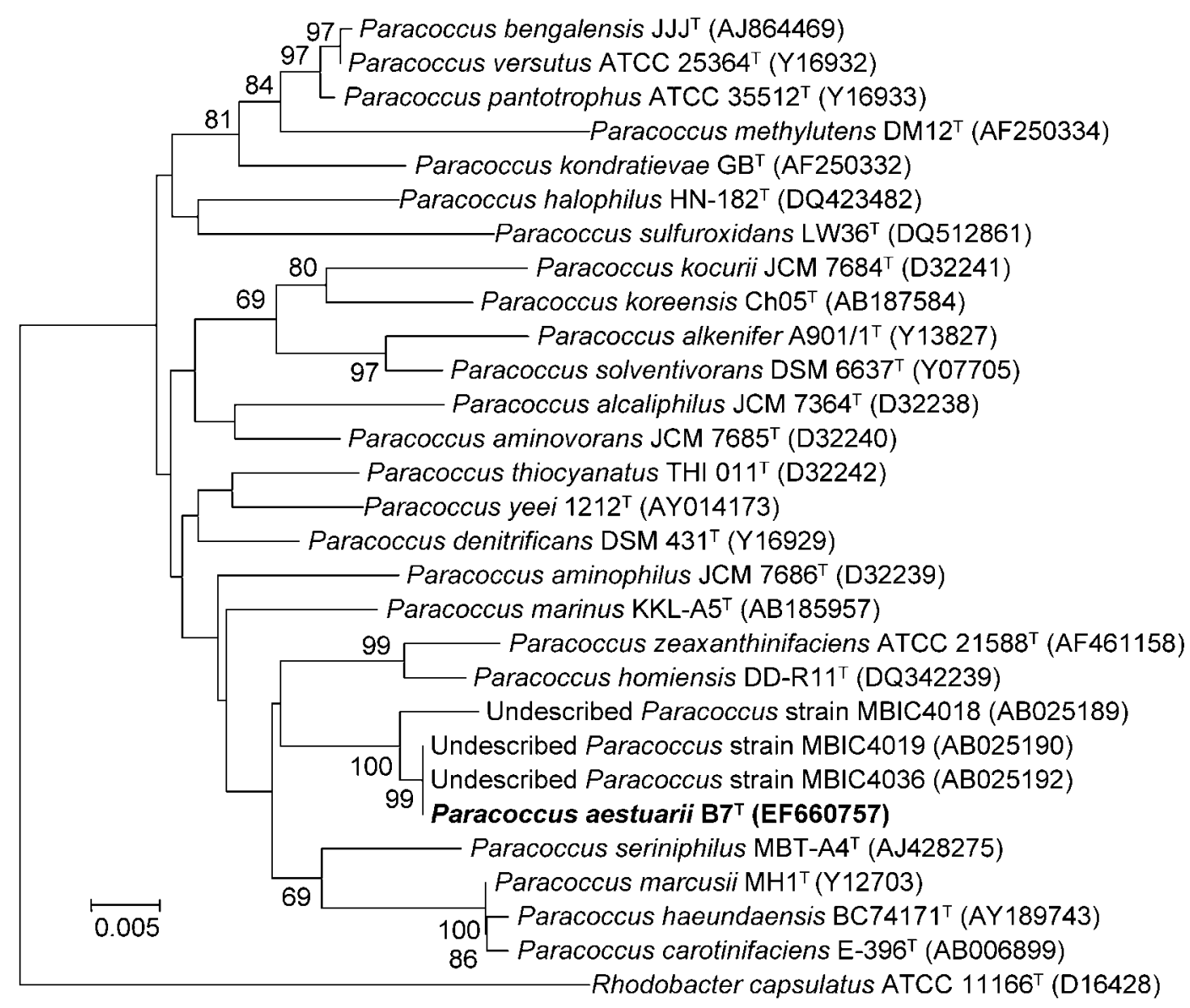

Fig. 1. Neighbour-joining phylogenetic tree, based on $16 \mathrm{~S}$ rRNA gene sequences, showing the position of strain $B 7^{\top}$ with respect to species in the genus Paracoccus. Numbers at nodes indicate bootstrap percentages (based on 1000 replications), where greater than $50 \%$. Bar, 0.005 accumulated changes per nucleotide. 
type strain of Paracoccus kocurii; Ohara et al., 1990). The $\mathrm{G}+\mathrm{C}$ content of the genomic DNA of strain $\mathrm{B}^{\mathrm{T}}$ is therefore within the range for recognized Paracoccus species.

The quantitative analysis of the cellular fatty acid composition was performed according to the instructions for the Sherlock Microbial Identification System (MIDI). Gas chromatography (6890; Hewlett Packard) together with the Microbial Identification software package (Sasser, 1990) were used to identify the fatty acids. The cellular fatty acids of strain $\mathrm{B}^{\mathrm{T}}$ were $\mathrm{C}_{18: 1} \omega 7 c(68.9 \%), \mathrm{C}_{18: 0}(18.1 \%)$, $\mathrm{C}_{10: 0} 3-\mathrm{OH}(2.5 \%), \mathrm{C}_{17: 0}(2.5 \%), \mathrm{C}_{16: 0}(1.3 \%)$, summed feature 2 (comprising $\mathrm{C}_{14: 0} 3-\mathrm{OH}$ and/or iso- $\mathrm{C}_{16: 1} \mathrm{I}$; $2.4 \%)$ and some others $(<1 \%)$. This profile, with $\mathrm{C}_{18: 1} \omega 7 \mathrm{c}$ as the major fatty acid, is characteristic of members of the genus Paracoccus. However, the $\mathrm{C}_{18: 1} \omega 7 \mathrm{c}$ $(68.9 \%)$ and $\mathrm{C}_{18: 0}(18.1 \%)$ contents of strain $\mathrm{B}^{\mathrm{T}}$ differed from the ranges (78.9-84.3\% and 2.5-7.8\%, respectively) found among the Paracoccus species ( $P$. marcusii, $P$. haeundaensis, $P$. carotinifaciens, $P$. seriniphilus, $P$. homiensis and P. zeaxanthinifaciens; Kim et al., 2006) that clustered with the novel strain in the phylogenetic tree. The differences in fatty acid composition may be the result of differences in experimental conditions.

Quinones were characterized as described by Collins (1985) and $\mathrm{Wu}$ et al. (1989). Paracoccus species are characterized as possessing ubiquinone-10 (Q-10). Strain $B 7^{\mathrm{T}}$ also possessed Q-10 as the sole respiratory quinone. This result, in combination with the $16 \mathrm{~S}$ rRNA gene sequence data, the $\mathrm{G}+\mathrm{C}$ content and the major fatty acid components, confirmed that the novel strain belongs to the genus Paracoccus.

Polar lipids were extracted and then examined by means of two-dimensional TLC followed by spray reagents (Collins et al., 1980). The polar lipid analysis indicated that strain $\mathrm{B}^{\mathrm{T}}$ contained phosphatidylcholine, phosphatidylglycerol and diphosphatidylglycerol.

To determine the optimum growth temperature for strain $\mathrm{B}^{\mathrm{T}}$, cells were grown on TSBA plates at $4-45^{\circ} \mathrm{C}$. The optimum $\mathrm{NaCl}$ concentration and $\mathrm{pH}$ were determined in TSB medium supplemented with $\mathrm{NaCl}(0-30 \%, w / v)$ and with $\mathrm{HCl}$ or $\mathrm{NaOH}$ (pH 4.0-13.0). Cell morphology was examined under light microscopy (ECLIPSE $80 i$; Nikon). Motility was observed using the wet-mount method (Murray et al., 1994) and Gram staining was performed with the non-staining method described by Buck (1982). Anaerobic growth was tested on TSBA plates using the BBL GasPak Pouch System (Becton Dickinson). Enzyme activities and substrate utilization from sole carbon sources were determined using API ZYM, API 20NE and API 50 $\mathrm{CH}$ test strips (bioMérieux). Catalase activity was investigated by assessing bubble production in a $3 \%(\mathrm{v} / \mathrm{v})$ hydrogen peroxide solution. A detailed species description is presented below and Table 1 shows a comparison between the characteristics of strain $\mathrm{B}^{\mathrm{T}}$ and those of six closely related strains (selected on the basis of $16 \mathrm{~S}$ rRNA
Table 1. Characteristics that serve to differentiate strain $B 7^{\top}$ from closely related species

Strains: $1, \mathrm{~B}^{\mathrm{T}}$ (P. aestuarii sp. nov.); 2, P. marcusii $\mathrm{MH}^{\mathrm{T}}$ (patent strain; data from Harker et al., 1998); 3, P. haeundaensis BC74171 ${ }^{\mathrm{T}}$ (patent strain; Lee et al., 2004); 4, P. carotinifaciens E-396 ${ }^{\mathrm{T}}$ (patent strain; Tsubokura et al., 1999); 5. P. seriniphilus MBT-A4 ${ }^{\mathrm{T}}$ (Pukall et al., 2003); 6. P. homiensis DD-R11 ${ }^{\mathrm{T}}$ (Kim et al., 2006); 7. P. zeaxanthinifaciens R-1512 ${ }^{\mathrm{T}}$ (Berry et al., 2003). +, Positive; -, negative; $\mathrm{W}$, weakly positive; NR, not reported.

\begin{tabular}{|lccccccc|}
\hline Characteristic & $\mathbf{1}$ & $\mathbf{2}$ & $\mathbf{3}$ & $\mathbf{4}$ & $\mathbf{5}$ & $\mathbf{6}$ & $\mathbf{7}$ \\
\hline Motility & - & - & - & + & - & + & - \\
Orange to red pigment & + & + & + & + & - & - & + \\
Growth at $40{ }^{\circ} \mathrm{C}$ & - & - & - & - & - & + & + \\
Growth with $6 \% \mathrm{NaCl}$ & - & $\mathrm{W}$ & + & $\mathrm{W}$ & + & + & + \\
Reduction of nitrate to & - & - & + & - & + & - & - \\
$\quad$ nitrite & & & & & & & \\
Urease activity & - & - & - & - & - & - & + \\
$\beta$-Glucosidase activity & + & + & $\mathrm{NR}$ & + & - & + & + \\
Growth on: & & & & & & & \\
$\quad$ Adonitol & + & + & - & + & + & - & - \\
Erythritol & - & + & $\mathrm{NR}$ & + & + & + & - \\
Gentiobiose & - & + & $\mathrm{NR}$ & + & - & - & - \\
L-Rhamnose & - & - & - & $\mathrm{NR}$ & - & + & - \\
D-Sorbitol & - & + & - & + & + & + & - \\
$\quad$ Xylitol & - & + & $\mathrm{NR}$ & + & + & - & - \\
DNA G+C content & 62.0 & 66 & 66.9 & 67 & 63.3 & 63 & 67.6 \\
$\quad$ (mol\%) & & & & & & & \\
\hline
\end{tabular}

gene sequence similarity and phylogenetic tree topology). Our detailed investigation has revealed genotypic and phenotypic differences between strain $\mathrm{B}^{\mathrm{T}}$ and recognized Paracoccus species.

Thus, on the basis of genetic, chemotaxonomic and phenotypic comparisons with previously described taxa, strain $B 7^{\mathrm{T}}$ represents a novel species of the genus Paracoccus, for which the name Paracoccus aestuarii sp. nov. is proposed.

\section{Description of Paracoccus aestuarii sp. nov.}

Paracoccus aestuarii (a.es.tu.a.ri'i. L. gen. n. aestuarii of a tidal flat).

Cells are aerobic, non-motile, rod-shaped $(0.8-1.0 \times 1.5-$ $2.0 \mu \mathrm{m}$ ), Gram-negative, catalase-positive and oxidasepositive. Colonies are orange-coloured, circular and approximately $1.0-2.5 \mathrm{~mm}$ in diameter after growth for 1 day on TSBA at $30{ }^{\circ} \mathrm{C}$. No growth occurs at $\mathrm{NaCl}$ concentrations greater than $5 \%$. The temperature range for growth is $15-37{ }^{\circ} \mathrm{C}$. The $\mathrm{pH}$ range for growth is 7.5-9.5 (optimum, $\mathrm{pH}$ 9.0). Nitrate is not reduced to nitrite or nitrogen, indole is not produced and glucose fermentation does not occur. Negative for arginine dihydrolase and urease. Aesculin and PNPG ( $p$-nitrophenyl- $\beta$-D-galactopyranoside) hydrolysis occurs, but not gelatin hydrolysis. D-Glucose, D-mannose, D-mannitol, $N$-acetylglucosamine, 
maltose, D-malate, trisodium citrate, D-ribose, D-xylose, Dadonitol, inositol, arbutin, aesculin, D-arabitol, L-arabitol, 2-ketogluconate and 5-ketogluconate are assimilated, but potassium gluconate, capric acid, adipic acid, phenylacetic acid, glycerol, erythritol, D-arabinose, L-arabinose, L-xylose, methyl $\beta$-D-xyloside, $\mathrm{D}$-galactose, $\mathrm{D}$-fructose, $\mathrm{L}$-sorbose, $\mathrm{L}$ rhamnose, dulcitol, D-sorbitol, methyl $\alpha$-D-mannoside, methyl $\alpha$-D-glucoside, amygdalin, salicin, cellobiose, Dlactose, melibiose, sucrose, trehalose, inulin, melezitose, raffinose, starch, glycogen, xylitol, gentiobiose, turanose, D-lyxose, D-tagatose, D-fucose and L-fucose are not assimilated. Positive for alkaline phosphatase, esterase (C4), esterase lipase (C8), leucine arylamidase, valine arylamidase, acid phosphatase, naphthol-AS-BI-phosphohydrolase, $\alpha$-galactosidase, $\beta$-galactosidase, $\alpha$-glucosidase and $\beta$-glucosidase. Negative for lipase (C14), cystine arylamidase, trypsin, $\alpha$-chymotrypsin, $\beta$-glucuronidase, $N$-acetyl- $\beta$-glucosaminidase, $\alpha$-mannosidase and $\alpha$-fucosidase. Predominant fatty acids are $\mathrm{C}_{18: 1} \omega 7 c, \mathrm{C}_{18: 0}, \mathrm{C}_{10: 0}$ 3-OH, $\mathrm{C}_{17: 0}, \mathrm{C}_{16: 0}$ and summed feature 2 (comprising $\mathrm{C}_{14: 0} 3-\mathrm{OH}$ and/or iso- $\left.\mathrm{C}_{16: 1} \mathrm{I}\right)$. The polar lipid fraction consists of phosphatidylcholine, phosphatidylglycerol and diphosphatidylglycerol. The major isoprenoid quinone is Q-10. The G + C content of genomic DNA of the type strain is $62.0 \mathrm{~mol} \%$.

The type strain, $\mathrm{B}^{\mathrm{T}}\left(=\right.$ KCTC $22049^{\mathrm{T}}=\mathrm{DSM} 19484^{\mathrm{T}}=\mathrm{JCM}$ $\left.15119^{\mathrm{T}}\right)$, was isolated from tidal flat sediment in Yeosu (34 $47^{\prime} 26^{\prime \prime} \mathrm{N} 127^{\circ} 34^{\prime} 01^{\prime \prime}$ E), South Korea.

\section{Acknowledgements}

We are grateful to Dr Jean P. Euzéby (École Nationale Vétérinaire, Toulouse, France) for his valuable advice on nomenclature for strain $B 7^{\mathrm{T}}$ and Dr Joseph Hirschberg (The Hebrew University of Jerusalem, Israel) for providing the patent strain $P$. marcusii $\mathrm{MH1}^{\mathrm{T}}$ for the DNA-DNA hybridization experiments. This work was supported by the KRIBB Research Initiative Program, the Eco-technopia 21 project, NMC0300837, the CAER (Centre for Aquatic Ecosystem Restoration) of Eco-STAR project, the 21C Frontier Microbial Genomics and Application Center Program and the Environmental Biotechnology National Core Research Center (Kosef: R15-2003-012-02002-0).

\section{References}

Berry, A., Janssens, D., Humbelin, M., Jore, J. P., Hoste, B., Cleenwerck, I., Vancanneyt, M., Bretzel, W., Mayer, A. F. \& other authors (2003). Paracoccus zeaxanthinifaciens sp. nov., a zeaxanthinproducing bacterium. Int J Syst Evol Microbiol 53, 231-238.

Buck, J. D. (1982). Nonstaining ( $\mathrm{KOH})$ method for determination of gram reactions of marine bacteria. Appl Environ Microbiol 44, 992993.

Chun, J., Lee, J. H., Jung, Y., Kim, M., Kim, S., Kim, B. K. \& Lim, Y. W. (2007). EzTaxon: a web-based tool for the identification of prokaryotes based on $16 \mathrm{~S}$ ribosomal RNA gene sequences. Int J Syst Evol Microbiol 57, 2259-2261.

Collins, M. D. (1985). Isoprenoid quinone analysis in classification and identification. In Chemical Methods in Bacterial Systematics, pp. 267-287. Edited by M. Goodfellow \& D. E. Minnikin. London: Academic Press.
Collins, M. D., Goodfellow, M. \& Minnikin, D. E. (1980). Fatty acid, isoprenoid quinone and polar lipid composition in the classification of Curtobacterium and related taxa. J Gen Microbiol 118, 29-37.

Davis, D. H., Doudoroff, M., Stanier, R. Y. \& Mandel, M. (1969). Proposal to reject the genus Hydrogenomonas: taxonomic implications. Int J Syst Bacteriol 19, 375-390.

Ezaki, T., Hashimoto, Y. \& Yabuuchi, E. (1989). Fluorometric deoxyribonucleic acid-deoxyribonucleic acid hybridization in microdilution wells as an alternative to membrane filter hybridization in which radioisotopes are used to determine genetic relatedness among bacterial strains. Int J Syst Bacteriol 39, 224-229.

Harker, M., Hirschberg, J. \& Oren, A. (1998). Paracoccus marcusii sp. nov., an orange gram-negative coccus. Int J Syst Bacteriol 48, 543-548.

Kim, B. Y., Weon, H. Y., Yoo, S. H., Kwon, S. W., Cho, Y. H., Stackebrandt, E. \& Go, S. J. (2006). Paracoccus homiensis sp. nov., isolated from a sea-sand sample. Int J Syst Evol Microbiol 56, 2387-2390.

Kimura, M. (1980). A simple method for estimating evolutionary rates of base substitutions through comparative studies of nucleotide sequences. J Mol Evol 16, 111-120.

Kumar, S., Tamura, K. \& Nei, M. (2004). MEGA3: integrated software for molecular evolutionary genetics analysis and sequence alignment. Brief Bioinform 5, 150-163.

Lane, D. J. (1991). 16S/23S rRNA sequencing. In Nucleic Acid Techniques in Bacterial Systematics, pp. 115-175. Edited by E. Stackebrandt \& M. Goodfellow. Chichester: Wiley.

Lee, J. H., Kim, Y. S., Choi, T. J., Lee, W. J. \& Kim, Y. T. (2004). Paracoccus haeundaensis sp. nov., a Gram-negative, halophilic, astaxanthin-producing bacterium. Int J Syst Evol Microbiol 54, 1699-1702.

Liu, X. Y., Wang, B. J., Jiang, C. Y. \& Liu, S. J. (2006). Paracoccus sulfuroxidans sp. nov., a sulfur oxidizer from activated sludge. Int $J$ Syst Evol Microbiol 56, 2693-2695.

Mesbah, M. \& Whitman, W. B. (1989). Measurement of deoxyguanosine/thymidine ratios in complex mixtures by high-performance liquid chromatography for determination of the mole percentage guanine + cytosine of DNA. J Chromatogr A 479, 297-306.

Murray, R. G. E., Doetsch, R. N. \& Robinow, F. (1994). Determinative and cytological light microscopy. In Methods for General and Molecular Bacteriology, pp. 21-41. Edited by P. Gerhardt, R. G. E. Murray, W. A. Wood \& N. R. Krieg. Washington, DC: American Society for Microbiology.

Ohara, M., Katayama, Y., Tsuzaki, M., Nakamoto, S. \& Kuraishi, H. (1990). Paracoccus kocurii sp. nov., a tetramethylammoniumassimilating bacterium. Int J Syst Bacteriol 40, 292-296.

Pukall, R., Laroche, M., Kroppenstedt, R. M., Schumann, P., Stackebrandt, E. \& Ulber, R. (2003). Paracoccus seriniphilus sp. nov., an L-serine-dehydratase-producing coccus isolated from the marine bryozoan Bugula plumosa. Int J Syst Evol Microbiol 53, 443-447.

Roh, S. W., Sung, Y., Nam, Y. D., Chang, H. W., Kim, K. H., Yoon, J. H., Jeon, C. O., Oh, H. M. \& Bae, J. W. (2008). Arthrobacter soli sp. nov., a novel bacterium isolated from wastewater reservoir sediment. J Microbiol 46, 40-44.

Saitou, N. \& Nei, M. (1987). The neighbor-joining method: a new method for reconstructing phylogenetic trees. Mol Biol Evol 4, 406-425.

Sasser, M. (1990). Identification of bacteria by gas chromatography of cellular fatty acids, MIDI Technical Note 101. Newark, DE: MIDI Inc.

Stackebrandt, E. \& Ebers, J. (2006). Taxonomic parameters revisited: tarnished gold standards. Microbiol Today 33, 152-155.

Thompson, J. D., Gibson, T. J., Plewniak, F., Jeanmougin, F. \& Higgins, D. G. (1997). The CLUSTAL_X windows interface: flexible 
strategies for multiple sequence alignment aided by quality analysis tools. Nucleic Acids Res 25, 4876-4882.

Tsubokura, A., Yoneda, H. \& Mizuta, H. (1999). Paracoccus carotinifaciens sp. nov., a new aerobic Gram-negative astaxanthinproducing bacterium. Int J Syst Bacteriol 49, 277-282.

Wayne, L. G., Brenner, D. J., Colwell, R. R., Grimont, P. A. D., Kandler, O., Krichevsky, M. I., Moore, L. H., Moore, W. E. C., Murray,
R. G. E. \& other authors (1987). International Committee on Systematic Bacteriology. Report of the ad hoc committee on reconciliation of approaches to bacterial systematics. Int J Syst Bacteriol 37, 463-464.

Wu, C., Lu, X., Qin, M., Wang, Y. \& Ruan, J. (1989). Analysis of menaquinone compound in microbial cells by HPLC. Microbiology [English translation of Microbiology (Beijing)] 16, 176-178. 